\title{
Admitting uncertainty, transforming engagement: towards caring practices for sustainability beyond climate change
}

\author{
Saurabh Arora ${ }^{1}$
}

Received: 30 December 2017 / Accepted: 16 June 2019 / Published online: 9 July 2019

(C) The Author(s) 2019

\begin{abstract}
Transformations to sustainability for addressing climate change are now more urgent than ever. This paper argues that such transformations are firstly required in modernist practices that militate against sustainability due to their constitution by the fallacy of human control. The latter points to the conceit of suppressing uncertainties in knowledge, commandeering agency from 'above', standardising governance, harming marginalised ecologies and disqualifying practices inferiorised as 'primitive', 'irrational' or 'vernacular'. Undoing the fallacy of control, by admitting uncertainties, modernist practices may become caring through transformative engagement with others. I propose four aspects of such transformative engagement: (a) egalitarian commitment to distributing epistemological privilege; (b) ontological sensitivity, by taking seriously the relational bases of others' knowing; (c) learning for divergence from others; and (d) affinity in alterity across widening divergence. These aspects are proposed not as fully formed principles, but rather as questions to be reworked in ongoing encounters and struggles for sustainability and climate justice. The aim is to nurture other-than-modern understandings of climate challenges and to help build multiple coexisting pathways of resilience, adaptation and mitigation.
\end{abstract}

Keywords Sustainability $\cdot$ Transformation $\cdot$ Resilience $\cdot$ Ecology of practices $\cdot$ Care in practice $\cdot$ Intercultural engagement

\section{Introduction}

Transformations to sustainability for addressing the challenges of climate change are now more urgent than ever. From melting ice caps to dying coral reefs and widespread droughts and famines, the challenges are piling up. Alongside many nonhuman species undergoing what is referred to as the sixth great extinction (Kolbert 2014), challenges include the vulnerabilities faced by poor people including rainfed farmers, small-scale fisherfolk, forest dwellers and 'indigenous' peoples living in ecologically sensitive areas (Adger et al. 2006; Sonwa et al. 2012; Barnes and Dove 2015).

In order to address such challenges, the development and adoption of novel techno-scientific means are often considered necessary. Indeed 'green' options (such as solar and wind power) in energy, agriculture and other sectors have been

Saurabh Arora

s.arora@sussex.ac.uk

1 Science Policy Research Unit, Jubilee Building, University of Sussex, Falmer, Brighton, UK adopted in many regions of the world, for climate change mitigation and for building resilience. Yet techno-scientific means, by themselves, cannot address the multiple challenges facing the vulnerable, who are often the poorest and most marginalised people in the world. Addressing these vulnerabilities requires sustainability transformations, geared towards social justice, economic equality and ecological regeneration (Leach et al. 2010). Such transformations tackle relations of power between government institutions and civil society; between large corporations and marginalised communities; across gendered, racial and ethnic divides; as well as across hierarchies based on expertise. Transformations are often driven by social movements from 'below' (Stirling 2014). They are coproduced with ecological change and techno-scientific developments (Haraway 1991; Jasanoff 2004), pointing to a socio-eco-technical appreciation of change.

I use the notion of socio-technical practices to appreciate sustainability transformations. Socio-technical practices are relational. They are performed by hybrid collectives of human beings and interrelated 'entities' such as technical artefacts, scientific models, economic interests, social norms, values and biophysical processes (Callon and Law 1997; Latour 2005). Socio-technical practices are characterised by 
uncertainties, because the socio-eco-technical worlds they address are extensively interconnected and complex. Human knowledge can only partially comprehend socio-ecotechnical worlds (Whitehead 1978). Furthermore, as the agency to bring about socio-eco-technical change is distributed across hybrid collectives, it is difficult to unambiguously define causal chains (Wynne 1992). This makes uncertain any predictions of well-defined trajectories of socio-ecotechnical change (Wynne 1992).

While uncertainties are inherent to socio-technical practices, they may be obscured or marginalised, particularly by knowledge practitioners attempting to gain legitimacy and authority associated with solid facts and stable artefacts (Callon et al. 2009). This legitimacy and authority then underpin modern aspirations of control (Stirling 2018), which is often directed towards nature and human beings 'inferiorised' on the basis of gender, race, class and so on (e.g. Lugones 2007; Quijano 2000). The same aspirations of control operate when practices of governments and intergovernmental institutions from 'above' are believed to be adequate, for addressing the profound challenges of climate change and of other forms of unsustainability associated with modernisation (e.g. toxic wastes, plastic in oceans, damaged landscapes, runaway inequalities and unquenchable consumption).

Instead, if uncertainties are admitted, it is clear that no single institution, discipline, movement, community or region can provide the answers for sustainability, which are required to move beyond climate change and other forms of unsustainability. Engaging with each other, however, diverse practitioners may produce plural understandings of climate challenges and multiple pathways of adaptation and mitigation (Zanotti and Palomino-Schalscha 2016; Stensrud 2016; Head and Gibson 2012). Such transformative engagement attempts to undo the modernist disqualification of diverse other-than-modern practices classified as 'traditional', 'vernacular', 'indigenous' and 'affective'. Transformative engagement is geared towards flattening epistemological and cultural hierarchies. It aims to bring the 'above' and 'below' together on an equal footing. Transformative engagement aims to realise caring practices which reject aspirations of control. Caring practices are critical for transformations to sustainability (Stirling 2018). I outline four bases of transformative engagement: (a) egalitarian commitment to distributing epistemological privilege; (b) ontological sensitivity, by taking seriously the relational bases of others' knowledge- making; (c) learning for divergence from others; and (d) affinity in alterity across widening divergence.

In articulating the four aspects of transformative engagement, I focus on encounters between socio-technical practices. This acknowledges that any practitioner is entangled in a hybrid collective of relations with other humans and nonhumans. So, when a practitioner engages with another, it is not just an encounter between two individuals but rather an engagement between two hybrid collectives that perform practices. This engagement is also embedded in a wider context constituted by other practices and material worlds. In short, as understood in this paper, engagement is widelydistributed beyond individual human practitioners.

Starting with a section to briefly conceptualise sociotechnical practices, as performed by hybrid collectives, I outline the problem associated with modernist practices drivenby aspirations of control (of socio-ecological worlds). A subsequent section outlines the four aspects of transformative engagement for addressing the challenges of climate change and other unsustainabilities (e.g. those associated with toxic chemicals in agriculture and plastic waste pollution). A final section offers some conclusions.

\section{Socio-technical practices}

Artefacts such as computer models developed/used to make climate change predictions may be presented as neutral and detached, but they are always entangled in wider relational worlds (Callon and Law 1997; Puig de la Bellacasa 2012). These relational worlds are hybrid, simultaneously socio-political, economic, ecological and technical. Such hybrid entanglement becomes apparent when attention is directed to the socio-technical practices in which an entity is made, adapted, used and repaired (Latour 2005; Graham and Thrift 2007). For example, climate simulation practices based on Global Circulation Models involve modellers' value judgments about 'the best' way to solve a problem (often, by quantifying uncertainties as risks) and about the relative importance of different metrics of success. These are entangled with multiple academic disciplines and physical locations, computer hardware and software, 'bits of code', 'initial data packages' and so on (Winsberg 2012: 127). Many of these entities embed histories of academic disciplines such as computer science and engineering. In such disciplines, the development and systematisation of methods and codes has been concentrated across knowledge institutions in the Global North. The latter institutions are even contracted to develop knowledge specifically for use by planners of adaptation and development in the Global South. An example is the climate modelling system PRECIS, developed by the UK Met Office Hadley Centre. The value judgments, assumptions, methods and codes embedded into the system by UK-based modellers are 'transferred' to a wide range of countries including India and South Africa. The latter regions' alternate practices of knowing are, as a result, made subordinate to or dependent on knowledge institutions based in 'advanced' Northern regions (Mahony and Hulme 2011).

Taking such (asymmetric) relations seriously, I approach practices as performed by hybrid collectives composed of 
interrelated human and nonhuman entities that are mutually adjusted to each other (Latour 1988; Callon and Law 1997). This implies that all action (of knowing) is distributed and relational. In pursuing their goals or intentions, human actors are constrained and enabled (in specific ways) by broader socio-ecological and political processes including nonhuman ecologies and technologies as well as cultural norms and moral values (Giddens 1984; Latour 1993; Shove et al. 2012). Together these 'entities'entangled with human bodies, constitute the hybrid collectives that perform practices. All constituent entities of hybrid collectives contribute to action (Latour 2005), in the sense that they enable and constrain other interrelated actors to make a difference in a situation. For example, a farmer's hybrid collective performing so-called climatesmart agriculture may involve technologies such as precision agriculture and plastic greenhouses (FAO 2011), which require the farmer to acquire new skills and knowledge. Yet the technologies' and the farmer's combined contribution to the action of food production (and hopefully, climate adaptation) is enabled and constrained by transnational firms attempting to maximise their profits through the development and 'transfer' of technological innovations, often with support from government institutions.

In general, the different entities constituting a hybrid collective are not equal or coeval. They hang together in relations of power, making unequal contributions and producing differential constraints on others (Latour 1988; Bennet 2010). Some entities in a collective, such as economic values of productive efficiency and profit, may exert greater influence on courses of action and therefore on the knowledge and artefacts produced. Thus, while some actors' interests and demands may be made central to performing a practice, those of many others may be marginalised or excluded (Stengers 2000: 46). Together these unequally-related interests, and associated norms and values, form what I term the ethos of a practice (Stengers 2010). The ethos of a practice is immanent to its hybrid collective, while being shaped by its milieu (see below). It is made and remade in action, as the practice is performed.

A hybrid collective is not a sovereign body. It is shaped by flows from/to a surrounding world or milieu. This milieu is composed of a wider/general environment of a collective, as well as its proximal/specific surroundings. The latter surroundings are carved as an outside by the particular practice, through the exclusion of specific entities from its hybrid collective. The excluded entities are those that are not aligned with other entities in the hybrid collective. For example, in carbon accounting practices enacted by countries, nonquantifiable effects of carbon emissions which are not captured by accounting frameworks, may be treated as part of the practices' proximal surroundings (Whitehead et al. 2007; Mahony and Hulme 2016). The wider environment of the same practices might be constituted by 'global' $\mathrm{CO}_{2}$ emissions that transcend national boundaries, and by neoliberal environmental governance that privileges quantitative accounting frameworks (Sullivan 2014). Overall, the milieu of a practice (composed of a wider environment and proximal surroundings), as well as the (unequal) relations between entities in the practice's hybrid collective, makes particular courses of action possible while closing down others (Stirling 2009).

The foregoing implies that knowing is not just a cognitive act, but rather a practice constituted by relational adjustments between different social, economic, ecological and technical entities. This means that the objects of (scientific) enquiry are not already out there in some natural form, waiting to be discovered by human actors. Instead, what is known about anything emerges out of relations between humans and nonhumans. An object of knowing may be isolated as a known fact, ex-post by science, but in the knowing act it is relationally entangled with other entities in a hybrid collective and its milieu. Thus, knowing is 'constituted by [relational] doing' (Stirling 2014: 19; Stirling 2016). Similarly, the knowledge involved in making, repairing and using material artefacts is also produced in and through action. And any understanding of such relational knowing doing is itself subject to uncertainties that characterise all knowledge practices (as detailed below).

\section{The problem of modernist practices}

As climate-related events exacerbate vulnerabilities to become disasters (UN 2015), and as the geological effects of planetary industrialisation, extractivism and waste become apparent in the so-called Anthropocene (Malhi 2017; Blaser and de la Cadena 2018), human impacts on organic and inorganic forms of life on Earth are clearly profound. However, considering the histories of international development, modern capitalism, colonialism and slavery, the responsibility for generating these impacts must not be attributed to a unified and homogeneous humanity (or the Anthropos). This unequal responsibility has been debated widely (in the context of climate change, see for example Agarwal and Narain 1991; Roberts and Parks 2007; Gardiner et al. 2010; and for a review of the debate around the Anthropocene, see Malhi 2017; Malm and Hornborg 2014). While providing an overview of these debates is beyond the scope of the present paper, a recognition of unequal responsibility for climate change serves as a central basis for the arguments presented below. However, rather than attributing primary responsibility for 'anthropogenic' production of climate change to particular world regions (e.g. those forming the core of the world economy or the metropole under colonialism), or to groups of capitalists (Moore 2014), I argue that such responsibility is better approached by focussing on sociotechnical practices which have been central to processes of modernisation (Mitchell 2002; Escobar 2010; Stengers 2015b), across capitalist, socialist and communist societies. 
It is now clear that modernisation processes, which have variously aligned (inter)national bureaucracies, factories, plantations, scientists, engineers, workers and consumers, are central to the production of climate change and wider unsustainability (Agarwal and Narain 1991; Sachs 2010; Malm and Hornborg 2014; Stengers 2015b). Requiring transformation therefore are the practices constituting modernisation, in order to tackle climate change and achieve sustainability (Stirling 2018). However, considering the wide diversity of socio-technical practices associated with modernisation in its various forms, I focus on transformations required in a subset of such practices that I term modernist.

Modernist practices can be performed in any part of the world, by any social group, in any cultural milieu. They are however likely to be driven from 'above', extending 'the illusion that top-down steering by governments and intergovernmental organisations alone can address global problems [such as climate change]' (Hajer et al. 2015: 1652). Crucially, modernist practices are characterised by human practitioners' aspiration to control nature and marginalised social groups (Quijano 2000; Mitchell 2002; Stirling 2014). This control however is rarely achieved in practice. It is a fallacy based on grandiose belief in (some) humans' ability to mould and master the world, often using techno-scientific knowledges and artefacts implicated in the enactment of social power (Foucault 1977). Following Mitchell (2002) and Stirling (2014, 2018), I consider this 'fallacy of control' to be a core ethos of modernist practices. This fallacy may manifest itself in one or more of the following five ways.

First, the fallacy of control is made manifest when modernist practices emphasise the precision and perfection of their artefacts such as nuclear reactors (Winner 1986), and large dams (Mitchell 2002). They attempt to suppress associated contingencies and uncertainties (e.g. regarding the disposal of wastes from nuclear power plants). Uncertainties here are distinct from risk that is calculable based on an event's probable occurrence (Callon et al. 2009). Under uncertainty, possible (future) states of the world are unknown (Knight 1964). Additionally, causal chains may not be fully identifiable and outcomes difficult to predict (Wynne 1992).

Second, modernist practices' fallacy of control becomes apparent when agency from 'above' is considered as the main driver of 'global' socio-eco-technical change such as that required for climate change mitigation or meeting the sustainable development goals (UN 2015). Such discursive appropriation of agency legitimises top-down 'cockpit-ism' (Hajer et al. 2015), while marginalising the work carried out by a wide range of socio-technical practices at the grassroots.

Third, modernist practices aim to standardise administrative governance, rather than preserving or proliferating diversity in a polity (Jasanoff 2006). They help develop standards based on narrow models of economic or environmental efficiency, to control deviation in a group of entities being governed. Deviating entities may be pushed to the margins or (violently) disciplined.

Fourth, modernist practices direct harm at (some) humans, for example by dumping toxic wastes on them or by making them vulnerable to extreme weather events (Carmin and Agyeman 2011). Such harm is often directed at people belonging to groups that have been controlled as 'inferior' or 'less capable' using categories of gender, race, caste and ethnicity (Lugones 2007; Quijano 2000). Modernist practices may also direct harm on animals, subjecting them to cruel tests (Twine 2010). They may dump toxic effluents contributing to air (or water) pollution on hybrid collectives composed of marginalised humans and nonhumans (e.g. Tilt 2013), often in the name of modernising development and progress.

Fifth, modernist practitioners mistake the specific ethos of their practices to be universal. They present their processes and products as generally valid, while acknowledging that the filling of implementation or application gaps may sometimes be necessary (Latour 1987). In this way, modernist practices attempt to grant themselves the legitimacy and authority 'to go everywhere, to enter any practical territory, to judge, deconstruct or disqualify what appears to them as illusions or folkloric beliefs and claims' (Stengers 2005: 191). By discursively separating nature from culture in their knowledges, modernist practices of knowing and governing have disqualified other practices as 'superstitious' or 'archaic'. This disqualification is directed most aggressively towards practices associated with groups relegated as 'inferior' by modernists. Such inferiorisation was done to people 'along any of the intersecting hierarchies, in the languages they spoke, in the costumes they wore, in the customs they inhabited, in the possible futures they could envision' (Trouillot 2002: 232).

Modernist practices also attempt to disqualify practices that resist against the fallacy of control embedded in specific techno-scientific interventions such as transgenic seeds or nuclear power. Those who resist may be dismissed as antiscience or anti-technology, and therefore anti-progress. In this way, modernist practices attempt to discipline progress itself (Stirling 2009, 2018).

It is clear from the foregoing that while many modern practices can be treated as modernist, not all techno-scientific and governance practices in the modern era have been constituted by the fallacy of control. For example, some modern practitioners have avoided standardisation becoming a straitjacket, by responding to local specificities in reconfiguring their practices. Others have tried to prevent harming marginalised living beings and paid attention to diversity (for some examples, see Tilley 2011; Ottinger and Cohen 2011). Such workers, engineers, doctors and scientists cannot be treated as modernist practitioners (as I have defined above).

Focussing on modernist practices, I ask how might they undergo transformation, by relinquishing the fallacy of control through engagement with other practices. 


\section{Transformations: from modernist to caring practices}

The transformations required from modernist practices are relational, attempted in engagement with diverse other practices. Transformative engagement, as outlined below, might enable practices to collectively become caring of vulnerable and neglected social and ecological worlds (Puig de la Bellacasa 2017). And in this way, cooperation may be afforded between diverse caring practices to address the challenges of climate change and wider unsustainability, through adaptation, mitigation and resilience-building activities.

The literature on care in practice is diverse and expanding. Arguably beginning as the 'ethics of care' articulated using the mother-child relation by Gilligan (1982), care has been associated with a wide range of practices including those found in hospitals, homes, laboratories, farms, youth work, in dealing with chemical contamination and taking care of soils under a changing climate (Pols 2004; Mol 2008; Mol et al. 2010; Wilson 2014; Puig de la Bellacasa 2017; Tironi and Rodríguez-Giralt 2017). The link to practices highlights that caring is 'much more than a moral stance' (Puig de la Bellacasa 2017: 4). It is a 'moral act', which requires 'not making value judgements, but engaging in practical activities'. (Mol 2008: 75). In practice, caring disavows modern hierarchies such as those between mind and body, subjects and objects, facts and values, thinking and acting, symbolic and material, as well as between ethical and affective (Mol 2008: 84). Building on Tronto (1993), Puig de la Bellacasa (2017: 4) offers a definition of care that emphasises these hybrid practical aspects: 'the affective and ethical dispositions involved in concern, worry and taking responsibility for others' wellbeing, such as 'caring about' and 'taking care of', [which] need to be supported by material practices'. Such affectiveethical dispositions in looking after damaged and neglected ecologies (of humans and nonhumans) constitute the ethos of caring practices. However, considering the difficulties entailed in figuring out the boundaries of collectives that perform caring practices (Giraud et al. 2018), and the reification risked in approaching the different cooperating hybrid collectives as discrete (Burman 2017), it is important to admit that any framing of caring practices and their (transformative) engagement will be subject to uncertainties of the kind discussed below.

Caring practices require 'a new style of concern, demanding that the dream of control or mastery be given up' (Stengers 2015a: 137). Caring practices admit uncertainties associated with their processes and outputs. Admitting uncertainties must not be equated with weakening or dilution of urgent messages such as those of climate action. Instead, by pointing to the complexity of reality and the difficulty of accurate prediction, by recognising the conditional validity of all knowledge (Wynne 2010), the admitting of uncertainties may make the presentation of climate change knowledge more rigorous and grounded. By helping cultivate humility (cf. Jasanoff 2003), the admitting of uncertainties points to the importance of cooperation between diverse ways of knowing, for promoting plural mitigation and adaptation options (Zanotti and Palomino-Schalscha 2016). Moreover, the admitting of uncertainties is not simply cognitive, restricted to gaps in knowledge as an output. Rather it is ontological, pointing to situatedness, intractability and precariousness associated with socio-technical practices of knowledge production.

Situatedness, as argued by Haraway (1991), points to the specific socio-eco-technical settings (or hybrid collectives) where knowledge production happens. Scientific knowledge is thus not a (disembodied) view from nowhere. Like all knowledge, it is an 'embodied view from somewhere' which is influenced not only by nonhuman processes but also by cultural values, social norms, economic interests and 'subjective' preferences. Caring practices present themselves in/to the world from 'below' as producers (and users) of situated and therefore partial knowledges.

Intractability arises due to the constituting relations of knowledge practices, between human 'knowers' and the worlds they address and assemble. Relations transform the entities that are connected. Relations also transform the meanings, procedures and materials that flow through them (Latour 2005). In this way, they introduce distortion, manipulation and invention, instead of standardisation (Arora et al. 2013). Ultimately, this makes it difficult to establish causal determinism and predict precise courses of action (Wynne 1992).

Precariousness points to the unfinished nature of practices, which in a socio-eco-technically dynamic world require constant adjustment and fine-tuning (Mol et al. 2010). These adjustments may be constrained by design, due to bureaucratic and/or epistemological control associated with modernist practices. They are however critical for users, situated in their own hybrid collectives, to ensure that the artefacts are workable using locally-available tools and resources (de Laet and Mol 2000). This means that practices and their (standardised) outputs cannot simply be 'scaled up'. Instead, they require adaptation (and repair) of their processes and products by later practitioners (Latour 1987). By admitting this precariousness, caring practitioners may become more attuned to taking responsibility for the performance of their process and outputs, rather than simply blaming 'unqualified' users for failures and adverse socio-ecological impacts.

In order to become caring, modernist practices (constituted by the fallacy of control) must undergo internal transformations, through engagement with diverse other practices that are also becoming-caring. The differences between the composition of modernist and becoming- 
Table 1 Characteristics of practices, from modernist to caring

\begin{tabular}{|c|c|c|}
\hline & Modernist (control) practices & Becoming-caring practices \\
\hline 1. & $\begin{array}{l}\text { Attempt to suppress uncertainties and } \\
\text { contingencies; }\end{array}$ & Admit uncertainties to cultivate humility; \\
\hline 2. & $\begin{array}{l}\text { Try to commandeer and appropriate agency } \\
\text { from 'above'; }\end{array}$ & $\begin{array}{l}\text { Acknowledge situatedness, and engage } \\
\text { with others from 'below'; }\end{array}$ \\
\hline 3. & $\begin{array}{l}\text { Aim to standardise governance based on } \\
\text { narrowly-defined efficiency; }\end{array}$ & $\begin{array}{l}\text { Account for the contribution to agency, } \\
\text { made by interrelated entities in their } \\
\text { hybrid collectives; }\end{array}$ \\
\hline 4. & $\begin{array}{l}\text { Often harm (marginalised) humans and other } \\
\text { living beings; }\end{array}$ & $\begin{array}{l}\text { Admit their precariousness and take } \\
\text { responsibility for their outputs; }\end{array}$ \\
\hline 5. & $\begin{array}{l}\text { Aim to extend modern universalism, while } \\
\text { disqualifying other-than-modern practices. }\end{array}$ & $\begin{array}{l}\text { Enact transformative engagement with } \\
\text { diverse other practices (as outlined below) }\end{array}$ \\
\hline
\end{tabular}

caring practices, as outlined above, are summarised in Table 1.

I do not make assumptions about an a priori caring ethos of any practice. I aim to avoid romanticisation of diverse 'indigenous' or 'traditional' practices. I acknowledge their heterogeneity, their dynamics, their hybridity and the various unequal relations of power constituting their performing collectives, from within and without. Caring transformations in practices are geared toward flattening all hierarchical relations within and between hybrid collectives. This means that caring practices embed and extend egalitarian relations, rather than structuring relations hierarchically using categories on intersecting ladders of rationality, 'civilisation', developmentalism, gender, class, race, caste, ethnicity, nationality and expertise (cf. Quijano 2000; Lugones 2007).

It is also important to point out that my plea for care is not the same as 'planetary stewardship' in the Anthropocene (Steffen et al. 2011; Schmidt et al. 2016) or 'more effective Earth system governance' (Biermann et al. 2012: 1306). Instead, I ask how care might be built by nurturing the diversity of socio-technical practices in the world, through transformative engagement with each other, while demanding that modernist practices be transformed. It is after all the latter practices that have been instrumental in producing much (ecological) injustice and inequality around the world. By placing the primary onus of transformation on modernist practices from 'above', I aim to make the case for an ethical stewardship that is not 'simply about human beings finding a technological or normative fix that will control and restore the Earth' (Gibson-Graham and Roelvink 2009: 322, in Ogden et al. 2013: 346). Caring as ethical stewardship in and through practices recognises that there are 'many legitimate histories and forms of knowledge production that arise from diverse cultures the world over' (Schmidt et al. 2016: 8). Yet, for this diversity to be maintained and nurtured, transformative intercultural engagement between practices may be required, which helps constitute radical (relational) interdependence rather than hierarchical ordering between groups of practitioners.

\section{Aspects of transformative engagement}

I argue that practices can become caring through transformative engagement with each other, of which I propose four conceptual aspects:

a. egalitarian commitment to sharing epistemological authority;

b. ontological sensitivity by taking seriously others' sociomaterial bases of knowing/making;

c. learning for divergence from others; and

d. affinity in alterity, for sustaining and growing divergence.

These four aspects are based on the recognition that addressing climate challenges requires that the trust historically placed in the certainty and accuracy of modern techno-scientific practices be distributed. Moving beyond modernist practices, transformative engagement proposes that the recognition of diverse (other-than-modern) practices as producers of knowledge and artefacts may be crucial for climate resilience and sustainability. These proposals of transformative engagement build on, yet are different from, earlier calls for participation in international development in three ways: First, I do not assume the existence of a priori categories of knowledges such as 'indigenous' and 'traditional', which are considered in need of revalorisation and engagement. Instead, I focus on transformations in modernist practices underpinned by the fallacy of control. Second, I do not focus on cooperation between knowledges or professions (e.g. agricultural scientists, extension officers and farmers), but rather on engagement between socio-technical practices, each of which comes with its own ontological bases. And third, in addition to focusing on transformative engagement between diverse practices across disciplines, institutions and cultures, I adopt a thoroughly relational approach to transformation, according to which engagement with others ends up recomposing practices from within, for achieving caring coexistence. The latter might be necessary to develop plural 
understandings of climate change and multiple adaptation/ mitigation pathways.

\section{Egalitarian commitment}

By presenting their facts and technologies as neutral, valuefree and complete, modernist techno-scientific experts have attempted to construct objects of knowing - social and natural phenomena - to be the same or similar everywhere (Mitchell 2002). Consequently, modernist practitioners promote their techno-scientific and socio-economic solutions as universally applicable. They claim their outputs to be 'superior' than the knowledges and artefacts produced by diverse other practices. This paves the way for the eventual substitution of the latter practices by modernist ones, often under modernisation programmes sponsored by states and capital. Similarly, modernist social scientific practices in disciplines such as economics are presented as producing systematizing knowledge that reveals the universal 'rationality of social life in ideal form'. (Mitchell 2002: 1). Encountering deviations from this ideal form in specific socio-ecological settings, modernist social sciences help design policy and planning interventions to control deviation. Deviating realities are disqualified as deviant and inefficient. Grounds are thus laid for formatting them through the extension of the assumed ideal of modernist rationality.

These issues are well documented, also in modernisation for climate adaptation and mitigation. Studies have for example shown how carbon markets, based on principles of neoclassical economics (Lohmann 2009), have failed to yield the promised mitigation (allowing emissions to continue in rich countries that buy cheap carbon credits from elsewhere). The same markets help extend modernist practices associated with unsustainable technologies such as industrial agrofuels and nuclear power (Böhm and Dabhi 2009; La Via Campesina 2010). In this way, also through instruments such as the clean development mechanism, market designs based on neoclassical economics displace alternate modes of economic organisation based on solidarity and community (Gibson-Graham and Roelvink 2009).

In order to address the foregoing concerns, I argue that modernist aspirations of control be abandoned. Such aspirations are based on the treatment of nature and diverse disqualified practices as objects that need to be studied for extraction out of their contexts and manipulated for maintaining unequal relations of power within and between practices. For enacting egalitarian commitment to sharing knowledgebased authority with diverse others, such objectification must be resisted and replaced with approaches that treat others as equal subjects who also do knowing (e.g. Fals-Borda and Rahman 1991).

Cultivating such an egalitarian commitment requires more than human will and desire. As practitioners, human beings' ability to transform is constrained by their socio-material entanglement in hybrid collectives. Here, appreciating the ontological multiplicity of things can be helpful in reconfiguring how practices engage with each other. Studying atherosclerosis in a Dutch hospital, Mol (2002) shows how the disease is enacted as a constriction of the arteries in the pathologists' laboratory, as pain in a patient's limb in the clinic, and as the loss of lumen in blood vessels under the radiologists' $\mathrm{x}$-rays. Thus, far from being treated as the 'same' disease everywhere, atherosclerosis is fluid and ontologically multiple, depending on the relational composition of the collectives in which it is known/performed. Another way to think about this multiplicity is the acceptance that only some aspects of the complex reality of atherosclerosis are enacted in a specific hybrid collective. Yet atherosclerosis is also a single disease, and accepted as such by disparate communities of patients, radiologists and clinicians.

Similarly, climate change may be a single global phenomenon, but one that is also ontologically multiple. The term climate change thus points to a multiplicity of realities observed by assembling hybrid collectives from specific biophysical and socio-political worlds (Esbjörn-Hargens 2011; Burman 2017). For example, in simulators' models, climate change is enacted as predicted increases in 'global mean temperature' under 'different carbon scenarios' (Winsberg 2012: 117). On field sites, climate change may be enacted as melting glaciers mapped by a hybrid collective composed of skilled human labour, measurement instruments, ideas of precision and drilling equipment (Mahony and Hulme 2016). Similarly, oceanographers may enact it as warming currents in the Gulf Stream. In disaster-prone regions, people may enact climate change as the increasing frequency of extreme weather events. And, policymakers and international negotiators at the IPCC may enact climate change as emission targets and plans for adaptation/mitigation activities (Beck and Mahony 2018).

Recognizing such ontological multiplicity does not weaken the case for climate action (Burman 2017). Instead, pointing to multiple realities of climate change, paves the way for appreciating the (equal) validity of divergent ways of knowing climate change. Each of these will then point to divergent adaptation and mitigation strategies. The coexistence of multiple strategies is facilitated by approaching divergent others as equal subjects of knowing. It is in this way that becomingcaring practitioners perform their egalitarian commitment to sharing cognitive authority with each other.

\section{Ontological sensitivity}

As noted above, perspectives on climate change may be multiple depending on the relational composition of the hybrid collectives in which they are performed/produced. For example, the Miriwoong people in Australia relate the changing 
climate to pressures from local development of dams and intensified agriculture. They also connect extreme weather events to 'spiritual retribution'. Overall, they do not 'separate climate from other drivers of change both in a material sense (dams, mines, and land use changes) and in a cosmological sense (it is not just the climate but also people who cause these changes)'. (Leonard et al. 2013: 630). Clearly then, the Miriwoong people are relying on very different hybrid collectives than climate scientists to produce their framings, even though they might be concerned about the 'same' issues as the scientists (e.g. extreme weather, changes in land use). Additionally, as the hybrid collectives behind their framings are changed, the Miriwoong people's framings are adjusted too, sometimes rather radically over time (and space). Paying attention to this changing relational composition of diverse other hybrid collectives, requires that caring practices take each other's ontological foundations seriously (Viveiros de Castro 2003; Candea 2011). This 'taking seriously' implies that caring practitioners slow down the explication of the processes and products of other practices, to not readily resolve others' knowledges into particulars and universals, truths and falsehoods, facts and fantasies (Stengers 2003).

First, slowing down simply demands that the hybrid worlds of other practices are not made explicit or transparent using one's own terms and criteria (Glissant 2010). This means that the possibilities and meanings of entities involved in performing other practices, are not directly actualised in one's own practice. The resulting opacity of other practices is used to wonder (by asking questions) about, rather than know or reveal, their ontological bases. It also implies deep reflexivity about what sustains others' practices as well as one's own practice. The latter implies questioning one's own assumptions and discerning what might otherwise be taken for granted and normalised (Stengers 2008).

Such ontological sensitivity cautions against approaching the knowing of diverse other practices as (social) scientific propositions that link independent and dependent variables (Deleuze and Guattari 1994: 22). The meanings and materials constructed by diverse other practices may be vastly different from those of the techno-sciences based on chains of reference or on explanatory relationships between functions and variables (Latour 1999; Deleuze and Guattari 1994). For example, Mr. Phiri Maseko, a famously successful water-harvesting farmer in Zimbabwe, uses metaphors rather than functions to explain his climate adaptation strategies (Mabeza 2013). Offering hospitality to the nonhumans on his farm as 'guests', attuning to the relations between soils, plants, people and water, he has developed a trap dam that he describes as an 'immigration centre'. He also highlights the critical importance, for adaptation, of soil and water 'marrying' with each other and 'raising a family together' (Wilson 2010, in Mabeza 2013: 132).

Second, ontological sensitivity implies that meanings developed by other practices are not particular manifestations of general notions, defined a priori, such as global carbon or climate resilience. Other practices' constituting notions are not specific reflections of a transcendent reality (or nature) underpinning general notions. Instead, their constituting meanings are to be approached as constructed and sustained by their own specific 'preconceptual ground' (Viveiros de Castro 2013: 484). This ground implies that the meanings constructed by other becoming-caring practices are immanent to their own socio-ecological-technical relational modalities. In one relational modality, non-human beings (in nature) may be treated as 'objects' lacking agency. In another, they may for example be approached as persons or as sacred beings (Blaser and de la Cadena 2018). Different relational modalities underpinning other caring practices give rise to plural conceptual meanings associated with 'common words' (Stengers 2011: 327), such as personhood and sacredness. This points to how conceptual pluralism is sustained by divergent socioeco-technical relational modalities.

In short, ontological sensitivity implies 'accepting alterity and equivocation as 'unsubsumable' by any transcendent point of view'. (Viveiros de Castro 2015: 9). Such alterity is material-relational. It is not reducible to symbolic, psychological or cognitive difference in thinking, describing and making. It is not reducible to differences in beliefs or any other representational systems. Rather it points to ontological differences, in the ways of relating entities, humans and nonhumans within and between hybrid collectives, as they undergo transformations to become caring.

\section{Learning for divergence}

Caring practices may find elements of other practices that are interesting to learn from. Historically, even in encounters where one of the practices was deemed 'inferior' by modernists, learning from the 'inferior' practices was nevertheless attempted (e.g. Parrish 2008). Such learning has been understood as appropriation from practices that are otherwise marginalised. In this process of appropriation, the ontological bases of inferiorised practices were and are eroded through land-grabbing and ecological destruction (Acosta 2013; McKay 2017). Additionally, appropriation may be used to extend and systematise modernist practices from 'above', extending their domination of the world through knowledge circulation (Raj 2013). Many cases of appropriation of people's diverse environmental or medical resources and knowledges have been documented (e.g. Mooney 2000; Hawthorne 2007; Griffiths 2008; Parsons and Nalau 2016).

In some cases of appropriation, such as bioprospecting, the UN's convention on biological diversity (CBD) stipulates that corporations must share economic benefits with the original owners of these resources including 'indigenous' communities in the global south (see e.g. Hayden 2007; Vermeylen and Walker 2011). Activists and scholars have however raised the 
issue whether economic benefits can be considered as adequate compensation if rising (international) demand for a product leads to deforestation and local resource depletion (Siddique 2016; AFP 2016), particularly if the latter leads to the erosion of the ontological bases of 'indigenous' practices. Profit-fuelled growth of a good may dramatically reconfigure the practices of its production/use, promoting standardised monocultures over sustainable polyculturing (Shiva 1988; Dawson et al. 2016). Similar growth may also be associated with powerful corporations' claims to intellectual property rights over people's community knowledges. Examples include the commodification of patented high-yielding seeds in climate-smart agriculture (ETC Group 2015), which replaces seed production and exchange among small farmers for building resilience (IAASTD 2009; De Schutter 2011).

For climate mitigation, based on the observation that conservation organisations' activities are very rarely informed by published research in conservation biology (Pullin et al. 2004), calls may be made for the biologists to engage more closely with local conservation practitioners on the ground. Biologists are advised to source research questions from the latter and carry out 'transdisciplinary social learning' with them for more effective decision-making (Knight et al. 2008: 614). However, in the name of democratic participatory and transdisciplinary processes, these ideas may obscure the political dynamics of appropriation of diverse other knowledges from marginalised peoples (Mosse 2001; Klenk and Meehan 2015). Such ideas also inadvertently promote 'convergence' or 'assimilationist' thinking based on the belief that (sustainable) development or progress is possible only along a single trajectory that is modernising or neoliberal (Gil-Riaño 2018; Stirling 2009; Peck 2004). As a result, the democratic politics of promoting plural divergent pathways to sustainability and resilience may be marginalised (Schulz and Siriwardane 2015; Kothari 2016).

In order to address this issue, for purposes of sustainable development and resilience, learning between diverse practitioners must be nonsubsumptive. It must nurture creative divergence, rather than standardisation, integration or convergence. Divergent and nonsubsumptive learning encounters do not erode the socio-material resources that sustain other practices. In such learning encounters, caring practices do not assimilate others, through convergence or integration, to constitute a single homogeneous we or us (Stengers 2010). In other words, such learning encounters further divergence of practices from each other.

This furthering of divergence may be necessary to keep the engaging practices interesting for each other to learn from. Continued learning may thus be contingent on sustaining divergences. Learning encounters between caring practices aim to make 'divergences exist' by 'naming and taking them into account' (Stengers 2015b: 141). For example, in developing climate resilient agriculture, learning encounters between agronomists promoting intensification technologies and farmers practising agroecology may account for the various ways in which their hybrid collectives diverge from each other. Such a process, for example, may focus on naming the differences between the relational modalities constituting their respective hybrid collectives. While intensification practices may be geared towards extracting higher yields out of land and labour in the short-run, ostensibly for sustainability and resilience (e.g. FAO 2011; Montpellier Panel 2013), agroecological practices may aim to assemble self-reliant hybrid collectives that cooperate to restore diverse ecosystems for a wide range of wild and domesticated species (e.g. Altieri and Toledo 2011). Rather than building a consensus to find the single best trajectory for climate-resilient agriculture, learning encounters between caring practitioners seek ways to support those (agroecological) practices that are marginalised by a powerful scientific-industrial complex that entrenches agricultural intensification (Vanloqueren and Baret 2009; ETC Group 2015; Levidow et al. 2019).

Learning for divergence may require that caring practitioners develop the capacity to distinguish 'good' from 'bad' encounters (Stengers 2008). In bad encounters, appropriation and assimilation of marginalised knowledges and resources are actualised. In good encounters, caring practitioners help each other to detect and value the distinctiveness of their respective practices. Such distinctiveness may be crucial to establish the importance of coexistence of divergent practices in efforts to build resilience and achieve wider sustainability. As with other aspects of transformative engagement outlined above, there is no standard prescription for developing the capacity to discern good encounters. This capacity itself points to a practice of learning that is contingent on the performance of encounters between becoming-caring practices. Previous encounters do not offer guarantees, apart from opportunities for learning how to respond by asking questions that can help discern what is good in new encounters (see below).

\section{Affinity in alterity}

By recognizing and sustaining divergence, through learning encounters, caring practices lay the foundations for a fourth aspect of transformative engagement: affinity with others who have been classified as 'inferior' by modernist practices using categories of rationality, civilisation, ethnicity, nationality, race and gender. Defying such inferiorisation, caring practitioners develop affinity not just on the basis of resemblance or commonality of characteristics with those that are alike, but also on appreciating and valuing widening divergence. This appreciation and valorisation is not the same as tolerance or respect, but rather it points to the active work of developing a new affinity for the practices that modernists have approached as 'inferior' due to their assumed irrationality and 
backwardness (Quijano 2007). Critically, such an affinity helps practitioners pose questions about their own subjectivity and how the ethos of their practices might be transformed to reject classifying and reifying other practices as 'inferior' (than one's own).

Practitioners routinely form affinity groups with others. This affinity is often developed through the following intersecting practices:

a. cultivating shared values such as environmentalism and climate justice;

b. organising similar tasks in professions and guilds, which may be translated into disciplinary and occupational communities such as physicists, farmers and weavers;

c. belonging to the 'same' gendered cultural identity intersecting with constructed nationality, race, class, caste and ethnicity.

The standard dictionary definition of affinity presents it as 'natural liking for someone or something', undergirded by 'a similarity of characteristics' (OED 2016). However, if we pay closer attention to the etymology of affinity, as the combination of $a d$ - (to) and finis (border), it may be reinterpreted as developing a liking from the vantage point offered by the margin of one's group(s). Practitioners at the margin are not only able to sense the ethos of the practices of their own group members, but also of other proximate practices in their milieu (cf. hooks 1989). At the margins, practitioners can thus discern the alterity (difference, variation) of other practices. This discernment of alterity inside and outside one's own group/ community can help practices become caring, by developing an affinity for the differences in the ethos of other practices.

On the margins, caring practitioners discern more than alterity, they also apprehend how hierarchical relations are constructed to order differences between their group(s) and other practitioners in their milieu. The process of constructing hierarchical relations might be viewed as beginning with the reduction of heterogeneous groups/communities of practitioners into distinct categories such as natural scientists and 'cultural' shamans, medical doctors and 'traditional' midwives and modern engineers and 'vernacular' craftspeople. Subsequently, differences between categories are identified and hierarchically ordered to stablish the superiority of some groups of practitioners as compared with others, based on assessments of their worth and capacities. These assessments rely on criteria framed by dominant groups of practitioners, which have benefitted from and provided justifications for the exercise of power such as that of modern colonialism (Quijano 2007). Assessment criteria have included (i) rationality based on narrow understandings of reason and logic; (ii) prosperity measured in monetary terms; purity based on the discursive separation of nature from culture; and (iii) advancement mapped according to presumed developmental maturity/ complexity.

Apprehending such processes of modernist assessment, caring practitioners must resist treating divergent practices hierarchically. This resistance has two implications. First, caring practices refrain from reducing myriad differences and divergences to oppositions. This does not imply the development of an 'affinity with the enemy' (Deleuze and Guattari 1994: 203). Instead, it is about transcending the notion of an enemy practitioner, by developing an affinity for that which is different and divergent in the ethos of other caring practices (while continuing to hold power to account).

Second, affinity in alterity demands that practitioners are reflexive about their belonging to a specific group. This reflexivity points to a recognition of how their authority to speak might be contingent on their belonging to a group of practitioners. The group may itself have been defined by constructing its irreducible difference from other practices categorised into groups such
Table 2 Transformative engagement between practices that are becoming caring

\begin{tabular}{|c|c|c|}
\hline $\begin{array}{l}\text { Aspect of } \\
\text { engagement }\end{array}$ & Based on the recognition of & Emphasises transformations toward \\
\hline $\begin{array}{l}\text { Egalitarian } \\
\text { commitment }\end{array}$ & $\begin{array}{l}\text { Ontological multiplicity of the 'same' } \\
\text { entity (or 'object' of knowing); }\end{array}$ & $\begin{array}{l}\text { Validity of divergent ways of knowing } \\
\text { (pointing to multiple climate adaptation } \\
\text { and mitigation pathways); }\end{array}$ \\
\hline $\begin{array}{r}\text { Ontological } \\
\text { sensitivity }\end{array}$ & $\begin{array}{l}\text { The relational dynamism of } \\
\text { socio-eco-technical worlds that } \\
\text { sustain other becoming-caring } \\
\text { practices; }\end{array}$ & $\begin{array}{l}\text { Slowing down the explication of other } \\
\text { practices by (a) wondering what sustains } \\
\text { them; (b) appreciating their } \\
\text { relational modalities; }\end{array}$ \\
\hline $\begin{array}{l}\text { Learning for } \\
\text { divergence }\end{array}$ & $\begin{array}{l}\text { Reversing appropriation and assimilation, } \\
\text { while undoing the disqualification of } \\
\text { other-than-modern practices; }\end{array}$ & $\begin{array}{l}\text { Nurturing creative divergence } \\
\text { (of adaptation/mitigation pathways) } \\
\text { and discerning 'good' from 'bad' } \\
\text { learning encounters; }\end{array}$ \\
\hline $\begin{array}{l}\text { Affinity in } \\
\text { alterity }\end{array}$ & $\begin{array}{l}\text { Reflexivity afforded by the margins of } \\
\text { groups/communities of practitioners, } \\
\text { for discerning alterity. }\end{array}$ & $\begin{array}{l}\text { Sustainability through affinity with } \\
\text { divergent others, while resisting the } \\
\text { hierarchical ordering of groups (as } \\
\text { 'superior' and 'inferior'). }\end{array}$ \\
\hline
\end{tabular}


as 'indigenous' and 'vernacular'. Engagement with these otherthan-modern practitioners is thus to be treated as 'a question of group-to-group relationship'. (Stengers 2011: 336). The group identity (and resulting authority) of a practitioner then serves as the basis of her engagement with others. The same identity is also an outcome of engagement between practices. Engaging practitioners help recognise differences and constitute the ethos of each other's practice.

A practitioner's identity is thus realised ecologically: its closure around a group of practitioners, and the extension of this closure to other spaces and times, serves as a 'condition of exchange' with other groups of practitioners (Stengers 2011: 337). Transforming this condition away from hierarchical ordering and the fallacy of control, through egalitarian commitment, ontological sensitivity and learning for divergence (rather than convergence), might be critical for realising multiple coexisting pathways to resilience and wider sustainability, with the aim of addressing and moving beyond the challenges of climate change.

\section{Summary of the argument}

It is critical that practical transformations to move beyond the challenges of climate change and other forms of unsustainability do not marginalise the multiple uncertainties that are inherent to all knowing (and the making of material artefacts). By marginalising (and even obscuring) uncertainties, extending standardisation and disqualifying other practices from 'above', modernist practices have historically gained the authority to dilute ontological differences, with impunity. By presenting their knowledges as complete facts, and their material artefacts as efficient and advanced, modernist practices have been targeted at controlling nature and diverse peoples inferiorised on the basis of modern categories associated with gender, race, ethnicity, nationality, rationality, 'civilisation', developmentalism and so on.

By transforming their practices through admitting uncertainties, modernist practitioners may be able to defy the fallacy of human control inherent to them. While such defiance helps cultivate humility, it does not erode the modern scientific basis for the urgency of climate action and sustainability. Accepting this urgency, it simply calls for pluralisation of socio-technical practices that are relevant for knowing climate change and for addressing adaptation, mitigation and resilience-building activities (aimed at achieving sustainability). Such pluralisation not only produces more comprehensive knowledge of climate change impacts and challenges, but it also points to multiple diverse pathways to sustainability (Stirling 2009). For such pluralisation and diversification to be realised, it is imperative that modernist practices be transformed. The latter transformation, through admitting uncertainties and affirming otherthan-modern ways of knowing, helps practices to become caring in engagement with diverse others (that are also becoming caring). In the foregoing, I have outlined four aspects of such transformative engagement, which are summarised in Table 2.

\section{Concluding remarks}

I have argued that resisting the fallacy of control underpinning modernist practices is critical in struggles for transformations to sustainability. Such resistance goes beyond critiquing modernity, in order to propose practical alternatives for sustainability, enacted relationally, through transformative engagement between diverse practices that are becoming caring towards neglected and marginalised socio-ecologies. By focusing on such transformations through caring practices, this paper contributes to emerging care-based understandings of sustainability that not only address the challenges of climate change but also other forms of unsustainability (e.g. plastic pollution, damaged landscapes and runaway inequalities).

Such transformations to sustainability are geared towards flattening hierarchies between practices from 'above' and 'below', by admitting uncertainties in knowing. They account for divergent ontological bases of other practices. They aim to undo modern appropriation and convergence. They nurture learning for divergence, and enact affinity for alterity. Overall, they aim to address climate vulnerabilities and achieve plural adaptation and mitigation pathways, while building resilience and sustainability in all three dimensions of social justice, economic equality and ecological regeneration.

Acknowledgements I thank Andy Stirling and Catherine Will for comments on a previous draft. Comments from REC's editors and anonymous reviewers have been very useful in producing the final version. This research was supported by funding from the ESRC, through grants ES/ N011414/1 and ES/I021620/1.

Open Access This article is distributed under the terms of the Creative Commons Attribution 4.0 International License (http:// creativecommons.org/licenses/by/4.0/), which permits unrestricted use, distribution, and reproduction in any medium, provided you give appropriate credit to the original author(s) and the source, provide a link to the Creative Commons license, and indicate if changes were made.

\section{References}

Acosta A (2013) Extractivism and neo-extractivism: two sides of the same coin. In: Lang M, Mokrani D (eds) Beyond development: alternative voices from Latin America. Transnational institute, Amsterdam, pp 61-86

Adger W, Paavola J, Huq S, Mace M (eds) (2006) Fairness in adaptation to climate change. The MIT Press, Cambridge

AFP (2016) Mexico's avocado boom causing deforestation and illnesses in local population, experts say. The Independent. http://www. independent.co.uk/news/world/why-you-should-stop-eating- 
avocados-immediately-mexico-environmental-damage-chemicalsa7397001.html. Accessed 1 Dec 2017

Agarwal A, Narain S (1991) Global warming in an unequal world: a case of environmental colonialism. Centre for Science and Environment, Delhi

Altieri M, Toledo V (2011) The agroecological revolution in Latin America: rescuing nature, ensuring food sovereignty and empowering peasants. J Peasant Stud 38:587-612. https://doi.org/ $10.1080 / 03066150.2011 .582947$

Arora S, Baan Hofman N, Koshti V, Ciarli T (2013) Cultivating compliance: governance of north Indian organic basmati smallholders in a global value chain. Environ Plan A 45:1912-1928. https://doi.org/ 10.1068/a45421

Barnes J, Dove M (eds) (2015) Climate cultures: anthropological perspectives on climate change. Yale University Press, New Haven and London

Beck S, Mahony M (2018) The IPCC and the new map of science and politics. WIREs Clim Chang 9:e547. https://doi.org/10.1002/wcc. 547

Bennet J (2010) Vibrant matter: a political ecology of things. Duke University Press, Durham

Biermann F, Abbot K, Andresen S, Backstrand K, Bernstein S, Betsill M, Bulkeley H, Cashore B, Clapp J, Folke C, Gupta A, Gupta J, Haas P, Jordan A, Kanie N, Kluvankova-Oravska T, Lebel L, Liverman D, Meadowcraft J, Mitchell R, Newell P, Oberthur S, Olsson L, Pattberg P, Sanchez-Rodriguez R, Schroeder H, Underdal A, Camargo Veira S, Vogel C, Brock A, Zondervan R (2012) Navigating the anthropocene: improving earth system governance. Science 335:1306-1307. https://doi.org/10.1126/science.1217255

Blaser M, de la Cadena M (2018) Pluriverse: proposal for a world of many worlds. In: de la Cadena M, Blaser M (eds) A world of many worlds. Duke University Press, Durham, pp 1-22

Böhm S, Dabhi S (2009) Upsetting the offset: the political economy of carbon markets. MayFlyBooks, London

Burman A (2017) The political ontology of climate change: moral meteorology, climate justice, and the coloniality of reality in the Bolivian Andes. J Polit Ecol 24:921-938. https://doi.org/10.2458/v24i1. 20974

Callon M, Law J (1997) After the individual in society: lessons on collectivity from science, technology and society. Can J Sociol 22:165182. https://doi.org/10.2307/3341747

Callon M, Lascoumes P, Barthe Y (2009) Acting in an uncertain world: an essay on technical democracy. The MIT Press, Cambridge

Candea M (2011) Endo/exo. Common Knowl 17:146-150. https://doi. org/10.1215/0961754x-2010-046

Carmin J, Agyeman J (2011) Environmental inequalities beyond borders: local perspectives on global injustices. The MIT Press, Cambridge

Dawson N, Martin A, Sikor T (2016) Green revolution in sub-Saharan Africa: implications of imposed innovation for the wellbeing of rural smallholders. World Dev 78:204-218. https://doi.org/10.1016/j. worlddev.2015.10.008

de Laet M, Mol A (2000) The Zimbabwe bush pump: mechanics of a fluid technology. Soc Stud Sci 30:225-263. https://doi.org/10.1177/ 030631200030002002

De Schutter O (2011) The right of everyone to enjoy the benefits of scientific progress and the right to food: from conflict to complementarity. Hum Rights Q 33:304-350. https://doi.org/10.1353/hrq. 2011.0020

Deleuze G, Guattari F (1994) What is philosophy? Columbia University Press, New York

Esbjörn-Hargens S (2011) An ontology of climate change: integral pluralism and the enactment of multiple objects. Journal of Integrative Theory and Practice 5:143-174

Escobar A (2010) Latin America at a crossroads. Cult Stud 24:1-65. https://doi.org/10.1080/09502380903424208
ETC Group (2015) Outsmarting nature? Synthetic biology and climate smart agriculture. ETC Group and Heinrich Böll Stiftung

FAO (2011) Save and grow: a policymaker's guide to the sustainable intensification of smallholder crop production. Food and Agriculture Organization of the United Nations, Rome

Fals-Borda O, Rahman M (Eds) (1991) Action and knowledge: breaking the monopoly with participatory action-research. The Apex Press, New York

Foucault M (1977) Discipline and punish: the birth of the prison. Vintage Books, New York

Gardiner S, Caney S, Jamieson D, Shue H (eds) (2010) Climate ethics: essential readings. Oxford University Press, Oxford

Gibson-Graham JK, Roelvink G (2009) An economic ethics for the Anthropocene. Antipode 41:320-346. https://doi.org/10.1111/j. 1467-8330.2009.00728.x

Giddens A (1984) The constitution of society: outline of the theory of structuration. Polity Press, Cambridge

Gilligan C (1982) In a different voice: psychological theory and women's development. Harvard University Press, Cambridge

Gil-Riaño S (2018) Relocating anti-racist science: the 1950 UNESCO statement on race and economic development in the global south. Br J Hist Sci 51:281-303. https://doi.org/10.1017/ S0007087418000286

Giraud E, Hollin G, Potts T, Forsyth I (2018) a feminist menagerie. Fem Rev 118:61-79. https://doi.org/10.1057/s41305-018-0103-1

Glissant E (2010) Poetics of relation. The University of Michigan Press, Ann Arbor

Graham S, Thrift N (2007) Out of order. Theory Cult Soc 24:1-25. https://doi.org/10.1177/0263276407075954

Griffiths T (2008) Seeing 'REDD'? Forest, climate change mitigation and the rights of indigenous peoples and local communities. Update for Poznań (UNFCCC COP 14). Forest Peoples Programme

Hajer M, Nilsson M, Raworth K, Bakker P, Berkhout F, de Boer Y, Rockström J, Ludwig K, Kok M (2015) Beyond cockpit-ism: four insights to enhance the transformative potential of the sustainable development goals. Sustainability 7(2):1651-1660

Haraway D (1991) Simians, cyborgs and women: the reinvention of nature. Routledge, New York

Hawthorne S (2007) Land, bodies, and knowledge: biocolonialism of plants, indigenous peoples, women, and people with disabilities. Signs 32:314-323. https://doi.org/10.1086/508224

Hayden C (2007) Taking as giving: bioscience, exchange, and the politics of benefit-sharing. Soc Stud Sci 37:729-758. https://doi.org/10. $1177 / 0306312707078012$

Head L, Gibson C (2012) Becoming differently modern: geographic contributions to a generative climate politics. Prog Hum Geogr 36:699714. https://doi.org/10.1177/0309132512438162

Hooks B (1989) Choosing the margin as a space of radical openness. In: Yearning: race, gender and cultural politics. South End Press, Boston, pp 145-154

IAASTD (2009) Agriculture at a crossroads: synthesis report. International Assessment of Agricultural Knowledge, Science and Technology for Development, Washinton, DC

Jasanoff S (2003) Technologies of humility: citizen participation in governing science. Minerva 41:223-244. https://doi.org/10.1023/a: 1025557512320

Jasanoff S (ed) (2004) States of knowledge: the co-production of science and social order. Routledge, London

Jasanoff S (2006) Biotechnology and empire: the global power of seeds and science. OSIRIS 21:273-292. https://doi.org/10.1086/507145

Klenk N, Meehan K (2015) Climate change and transdisciplinary science: problematizing the integration imperative. Environ Sci Pol 54:160 167. https://doi.org/10.1016/j.envsci.2015.05.017

Knight F (1964) Risk, uncertainty and profit. Sentry Press, New York

Knight A, Cowling R, Rouget M, Balmford A, Lombard A, Campbell B (2008) Knowing but not doing: selecting priority conservation areas 
and the research-implementation gap. Conserv Biol 22:610-617. https://doi.org/10.1111/j.1523-1739.2008.00914.x

Kolbert E (2014) The sixth extinction: an unnatural history. Picador, New York

Kothari A (2016) The search for radical alternatives: key elements and principles. Countercurrents.org, November 03, https:// countercurrents.org/2016/11/03/the-search-for-radical-alternativeskey-elements-and-principles/

La Via Campesina (2010) The people create thousands of solutions to confront climate change! https://viacampesina.org/en/the-peoplecreate-thousands-of-solutions-to-confront-climate-change/. Accessed 1 Sept 2018

Latour B (1987) Science in action: how to follow scientists and engineers through society. Harvard University Press, Cambridge

Latour B (1988) The pasteurisation of France. Harvard University Press, Cambridge

Latour B (1993) We have never been modern. Harvard University Press, Cambridge

Latour B (1999) Pandora's hope: essays on the reality of science studies. Harvard University Press, Cambridge

Latour B (2005) Reassembling the social: an introduction to actornetwork theory. Oxford University Press, Oxford

Leach M, Scoones I, Stirling A (2010) Dynamic sustainabilities: technology, environment, social justice. Earthscan, London

Leonard S, Parsons M, Olawsky K, Kofod F (2013) The role of culture and traditional knowledge in climate change adaptation: insights from East Kimberley, Australia. Glob Environ Chang 23:623-632. https://doi.org/10.1016/j.gloenvcha.2013.02.012

Levidow L, Nieddu M, Vivienne F-D, Befort N (2019) Transitions toward a European bioeconomy: life sciences versus agroecology trajectories. In: Allaire G, Daviron B (eds) Ecology, capitalism and the new agricultural economy: the second great transformation. Routledge, London, pp 181-203

Lohmann L (2009) Neoliberalism and the calculable world: the rise of carbon trading. In: Böhm S, Dabhi S (eds) Upsetting the offset: the political economy of carbon markets. MayFlyBooks, London, pp $25-40$

Lugones M (2007) Heterosexualism and the colonial/modern gender system. Hypatia 22:186-209. https://doi.org/10.1111/j.1527-2001. 2007.tb01156.x

Mabeza C (2013) Metaphors for climate adaptation from Zimbabwe: Zephaniah Phiri Maseko and the marriage of water and soil. In: Green L (ed) Contested ecologies: dialogues in the south on nature and knowledge. HSRC Press, Cape Town, pp 126-139

Mahony M, Hulme M (2011) Model migrations: mobility and boundary crossings in regional climate prediction. Trans Inst $\mathrm{Br}$ Geogr 37: 197-211. https://doi.org/10.1111/j.1475-5661.2011.00473.x

Mahony M, Hulme M (2016) Epistemic geographies of climate change: science, space and politics. Prog Hum Geogr 42. https://doi.org/10. $1177 / 0309132516664800$

Malhi Y (2017) The concept of the Anthropocene. Annu Rev Environ Resour 42:25.1-25.28. https://doi.org/10.1146/annurev-environ102016-060854

Malm A, Hornborg A (2014) The geology of mankind? A critique of the Anthropocene narrative. Anthropocene Rev 1:62-69. https://doi. org/10.1177/2053019613516291

McKay B (2017) Agrarian extractivism in Bolivia. World Dev 97:199_ 211. https://doi.org/10.1016/j.worlddev.2017.04.007

Mitchell T (2002) Rule of experts: Egypt, technopolitics, modernity. University of California Press, Berkeley

Mol A (2002) The body multiple: ontology in medical practice. Duke University Press, Durham

Mol A (2008) The logic of care: health and the problem of patient choice. Routledge, London
Mol A, Moser I, Pols J (eds) (2010) Care in practice: tinkering in clinics, homes and farms. Verlag, Bielefeld. DOI: https://doi.org/10.14361/ transcript.9783839414477

Mooney P (2000) Why we call it biopiracy? In: Svarstad H, Dhillon S (eds) Responding to bioprospecting: from biodiversity in the south to medicines in the north. Spartacus, Oslo, pp 37-44

Moore J (2014) Capitalocene: Part I and II. Fernand Braudel Center, Binghampton University

Mosse D (2001) People's knowledge, participation and patronage: operations and representations in rural development. In: Cooke B, Kothari U (eds) Participation: the new tyranny. Zed Press, London, pp 16-35

OED (2016) Oxford English Dictionary. Oxford, UK

Ogden L, Heynen N, Oslender U, West P, Kassam K-A, Robbins P (2013) Global assemblages, resilience, and earth stewardship in the Anthropocene. Fronti Ecol Environ 11:341-347. https://doi.org/10. $1890 / 120327$

Ottinger G, Cohen B (eds) (2011) Technoscience and environmental justice: expert cultures in a grassroots movement. The MIT Press, Cambridge

Parsons M, Nalau J (2016) Historical analogies as tools in understanding transformation. Glob Environ Chang 38:82-96. https://doi.org/10. 1016/j.gloenvcha.2016.01.010

Parrish S (2008) Diasporic African sources of enlightenment knowledge. In Delbourgo J and Dew N (eds) Science and empire in the Atlantic world. Routledge, London, pp. 281-310

Peck J (2004) Geography and public policy: constructions of neoliberalism. Prog Hum Geogr 28:392-405. https://doi.org/10.1191/ 0309132504ph492pr

Pols J (2004) Good care: enacting a complex ideal in long-term psychiatry. $\mathrm{PhD}$ Thesis, Universiteit Twente, The Netherlands

Puig de la Bellacasa M (2012) 'Nothing comes without its world': thinking with care. Sociol Rev 60:197-216. https://doi.org/10.1111/j. 1467-954X.2012.02070.x

Puig de la Bellacasa M (2017) Matters of care: speculative ethics in more than human worlds. University of Minnesota Press, Minneapolis

Pullin A, Knight T, Stone D, Charman K (2004) Do conservation managers use scientific evidence to support their decision-making? Biol Conserv 119:245-252. https://doi.org/10.1016/j.biocon.2003.11. 007

Quijano A (2000) Coloniality of power, eurocentrism and Latin America, vol 1. Views from the South, Nepantla, pp 533-580

Quijano A (2007) Coloniality and modernity/rationality. Cult Stud 21: 168-178. https://doi.org/10.1080/09502380601164353

Raj K (2013) Beyond postcolonialism ... and postpositivism: circulation and the global history of science. Isis 104:337-347. https://doi.org/ $10.1086 / 670951$

Roberts J, Parks B (2007) Fueling injustice: globalization, ecological unequal exchange and climate change. Globalizations 4:193-210. https://doi.org/10.1080/14747730701345218

Sachs W (2010) Preface to the new edition. In: Sachs W (ed) The development dictionary: a guide to knowledge as power, 2nd edn. Zed books, London, pp vi-xiv

Schmidt J, Brown P, Orr C (2016) Ethics in the anthropocene: a research agenda. Anthropocene Rev 3:188-200. https://doi.org/10.1177/ 2053019616662052

Schulz K, Siriwardane R (2015) Depoliticised and technocratic? Normativity and the politics of transformative adaptation. Earth System Governance Working Paper no. 33, Lund and Amsterdam

Shiva V (1988) Staying alive: women, ecology and survival in India. Zed Books, London

Shove E, Pantzar M, Watson M (2012) The dynamics of social practice: everyday life and how it changes. Sage, London

Siddique H (2016) Rising avocado prices fuelling illegal deforestation in Mexico. The Guardian. https://www.theguardian.com/lifeandstyle/ 
2016/aug/10/avocado-illegal-deforestation-mexico-pine-forests. Accessed 1 Dec 2017

Sonwa D, Somorin O, Jum C, Bele M, Nkem J (2012) Vulnerability, forest-related sectors and climate change adaptation: the case of Cameroon. Forest Policy Econ 23:1-9. https://doi.org/10.1016/j. forpol.2012.06.009

Steffen W, Persson A, Deutsch L, Zalasiewicz J, Williams M, Richardson K, Crumley C, Crutzen P, Folke C, Gordon L, Molina M, Ramanathan V, Rockström J, Scheffer M, Schellnhuber H, Svedin U (2011) The Anthropocene: from global change to planetary stewardship. Ambio 40:739-761. https://doi.org/10.1007/s13280-011$0185-\mathrm{x}$

Stengers I (2000) Another look: relearning to laugh. Hypatia 15:41-54. https://doi.org/10.1111/j.1527-2001.2000.tb00348.x

Stengers I (2003) The doctor and the charlatan. Cult Stud Rev 9:11-36. https://doi.org/10.5130/csr.v9i2.3561

Stengers I (2005) Introductory notes on an ecology of practices. Cult Stud Rev 11:183-196. https://doi.org/10.5130/csr.v11i1.3459

Stengers I (2008) Experimenting with refrains: subjectivity and the challenge of escaping modern dualism. Subjectivity 22:38-59. https:// doi.org/10.1057/sub.2008.6

Stengers I (2010) Cosmopolitics I. University of Minnesota Press, Minneapolis

Stengers I (2011) Cosmopolitics II. University of Minnesota Press, Minneapolis

Stengers I (2015a) Accepting the reality of Gaia: a fundamental shift? In: Hamilton C, Bonneuil C, Gemenne F (eds) The anthropocene and the global environmental crisis: rethinking modernity in a new epoch. Routledge, London

Stengers I (2015b) In catastrophic times: resisting the coming barbarism. Open Humanities Press

Stensrud A (2016) Climate change, water practices and relational worlds in the Andes. Ethnos 81:75-98. https://doi.org/10.1080/00141844. 2014.929597

Stirling A (2009) Direction, distribution and diversity! Pluralising progress in innovation, sustainability and development. STEPS Centre, Brighton

Stirling A (2014) Emancipating transformations: from controlling the 'transition' to culturing plural radical progress. STEPS Centre, Brighton

Stirling A (2016) Knowing doing governing: realizing heterodyne democracies. In: Voß J-P, Freeman R (eds) Knowing governance: the epistemic construction of political order. Palgrave Macmillan UK, London, pp 259-289. doi:https://doi.org/10.1057/9781137514509_12

Stirling A (2018) Sustainability and the politics of transformations: from control to care in moving beyond modernity. Draft Chapter In: Meadowcroft et al. (eds) What next for sustainable development? Our common future at thirty

Sullivan S (2014) The natural capital myth; or will accounting save the world? LCSV Working Paper Series No. 3, Leverhulme Centre for the Study of Value, The University of Manchester

The Montpellier Panel (2013) Sustainable intensification: a new paradigm for African agriculture, London

Tilley H (2011) Africa as a living laboratory: empire, development, and the problem of scientific knowledge, 1870-1950. University of Chicago Press, Chicago

Tilt B (2013) Industrial pollution and environmental health in rural China: risk, uncertainty and individualization. China Q 214:283-301. https://doi.org/10.1017/s0305741013000350
Tironi M, Rodríguez-Giralt I (2017) Healing, knowing, enduring: care and politics in damaged worlds. Sociol Rev Monogr 65:89-109. https://doi.org/10.1177/0081176917712874

Tronto J (1993) Moral boundaries: a political argument for an ethic of care. Routledge, New York

Trouillot M (2002) The otherwise modern: Caribbean lessons from the savage slot, in Bruce M. Knauft (Ed) Critically modern: alternatives, alterities, anthropologies. Indiana University Press, Bloomington

Twine R (2010) Animals as biotechnology: ethics, sustainability and critical animal studies. Earthscan, London

UN (2015) Sendai framework for disaster risk reduction 2015-2030. UNISDR

Vanloqueren J, Baret P (2009) How agricultural research systems shape a technological regime that develops genetic engineering but locks out agroecological innovations. Res Policy 38:971-983. https://doi.org/ 10.1016/j.respol.2009.02.008

Vermeylen S, Walker G (2011) Environmental justice, values, and biological diversity: the san and the hoodia benefit-sharing agreement. In: Carmin J, Agyeman J (eds) Environmental inequalities beyond borders: local perspectives on global injustices. The MIT Press, Cambridge, pp 105-128

Viveiros de Castro E (2003) (Anthropology) and (science). After Dinner Speech at the 5th Decennial Conference of the Association of Social Anthropologists of Great Britain and Commonwealth, Manchester Papers in Soc Anthropol 7

Viveiros de Castro E (2013) The relative native. HAU J Ethnogr Theory 3:473-502. https://doi.org/10.14318/hau3.3.032

Viveiros de Castro E (2015) Who is afraid of the ontological wolf? Some comments on an ongoing anthropological debate. Camb J Anthrop 33:2-17. https://doi.org/10.3167/ca.2015.330102

Whitehead AN (1978) Process and reality: an essay in cosmology. The Free Press, New York

Whitehead M, Jones R, Jones M (2007) The nature of the state: excavating the political ecologies of the modern state. Oxford University Press, Oxford

Wilson KB (2010) Overview of Zephaniah Phiri's book of life, at his lifetime achievement award. Speech given at University of Zimbabwe, August 24th

Wilson E (2014) Engaging youth on their own terms? An actor-network theory account of hip-hop in youth work. PhD Thesis, University of Canterbury

Winsberg E (2012) Values and uncertainties in predictions of global climate models. Kennedy Inst Ethics J 22:111-137. https://doi.org/10. 1353/ken.2012.0008

Winner L (1986) The whale and the reactor: a search for limits in an age of high technology. The University of Chicago Press, Chicago

Wynne B (1992) Uncertainty and environmental learning: reconceiving science and policy in the preventive paradigm. Glob Environ Chang 2:111-127. https://doi.org/10.1016/0959-3780(92)90017-2

Wynne B (2010) Strange weather, again: climate science as political art. Theory Cult Soc 27:289-305. https://doi.org/10.1177/ 0263276410361499

Zanotti L, Palomino-Schalscha M (2016) Taking different ways of knowing seriously: cross-cultural work as translations and multiplicity. Sustain Sci 11:139-152. https://doi.org/10.1007/s11625-015-0312-x

Publisher's note Springer Nature remains neutral with regard to jurisdictional claims in published maps and institutional affiliations. 